\title{
Analisis Tingkat Kesehatan PT. Bank Aceh Dengan Menggunakan Metode CAMEL
}

\author{
Safrizal $^{1}{ }^{*}$, Hadi Muttaqin ${ }^{1}$, Heppy $^{2}$, Indra Akbar ${ }^{3}$, Ricky Ariansyah $^{3}$, Lisnawati $^{4}$, Mirnawati ${ }^{3}$ \\ ${ }^{1}$ Prodi Akuntansi, Politeknik Kutaraja, Banda Aceh, Indonesia \\ ${ }^{2}$ Prodi Manajemen Keuangan Sektor Publik, Politeknik Kutaraja, Banda Aceh, Indonesia \\ ${ }^{3}$ Prodi Administrasi Perkantoran, Politeknik Kutaraja, Banda Aceh, Indonesia \\ ${ }^{4}$ Prodi Analis Keuangan, Politeknik Kutaraja, Banda Aceh, Indonesia \\ Email: ${ }^{1 *}$ safrizal.bbc@gmail.com, ${ }^{2}$ hdmuttaqin@gmail.com, ${ }^{3}$ heppy@ poltekkutaraja.ac.id, \\ ${ }^{4}$ indraakbar@poltekkutaraja.ac.id, ${ }^{5}$ rickyariansyah@poltekkutaraja.ac.id, ${ }^{6}$ lisnawati@poltekkutaraja.ac.id, \\ ${ }^{7}$ mirnawati@poltekkutaraja.ac.id
}

\begin{abstract}
Abstrak
Perkembangan aktifitas perbankan yang sangat pesat serta tingkat kompleksitas yang tinggi dapat mempengaruhi kondisi suatu bank. Kompleksitas usaha perbankan yang tinggi dapat meningkatkan resiko yang dihadapi oleh bank-bank yang ada di Indonesia. Tujuan penelitian ini adalah untuk mengetahui tingkat kesehatan PT. Bank Aceh periode 2012 sampai 2014. Penelitian ini merupakan penelitian deskriptif kuantitatif dengan menggunakan metode CAMEL yang meliputi Faktor Permodalan (Capital), Kualitas Aktiva (Asset Quality), Rentabilitas (Earning), dan Likuiditas (Liquidity). Berdasarkan analisis diketahui bahwa secara keseluruhan dapat dinyatakan PT. Bank Aceh dalam kondisi Sangat Sehat dan menempatkan pada posisi-1 berdasarkan ketentuan yang sudah dibuat oleh Bank Indonesia.
\end{abstract}

Kata Kunci: Tingkat Kesehatan Bank, Metode CAMEL

\section{PENDAHULUAN}

Peran perbankan dalam menunjang aktifitas perekonomian diperlukan suatu kondisi perbankan yang sehat. Guna menunjang keperluan tersebut diperlukan suatu analisis untuk mengetahui tingkat kesehatan bank pada jangka waktu tertentu. PT Bank Aceh merupakan salah satu bank yang memegang peranan penting terhadap kemajuan Aceh sejak mulai berdiri. PT Bank Aceh sebagai badan usaha milik daerah (BUMD) sudah semestinya mampu memberikan kontribusi yang maksimal terhadap pembangunan daerah dengan memberikan kinerja yang baik. Kinerja keuangan sebuah lazim diukur dengan tingkat kesahatan bank sesuai dengan aturan Bank Indonesia. Dalam penentuan tingkat kesahatan sebuah bank, Bank Indonesia menetakan indikator mencakup aspek permodalan (capital), kekayaan bank (assets), manajemen dan kepatuhan (management), tingkat profitabilitas (earning), likuiditas (likuidities) serta sensitabilitas (sensitibalities). Namun secara umum yang sering diguakan hanya 5 (lima) aspek tanpa sensitabilitas. Kelima aspek ini dikenal dengan istilah CAMEL yang merupakan akronim dari Capital, Assets, Management, Earning, Liquidities.

\section{METODOLOGI PENELITIAN}

Setiap perusahaan bertujuan untuk memaksimalkan kekayaan dari pemegang sahamnya. Pertumbuhan ekonomi tentunya membutuhkan indikator yang jelas sehingga dapat tergambarkan pasang surutnya perekonomian sebuah negara. Salah satu indikator yang digunakan adalah pertumbuhansektor keuangan yang stabil dan mantap [1]. Pengukuran kinerja keuangan perusahaan diperlukan untuk menentukan keberhasilan dalam mencapai tujuan tersebut [2]. Rasio CAMEL adalah rasio yang menggambarkan suatu hubungan atau perbandingan antara suatu jumlah tertentu dengan jumlah yang lain terdapat dalam laporan keuangan suatu lembaga keuangan. CAMEL terdiri atas lima kriteria yaitu Modal (Capital), Aktiva (Asset), Manajemen (Management), Pendapatan (Earning), dan Likuiditas (Likuidity). Peringkat CAMEL dibawah 81 memperlihatkan kondisi keuangan lemah yang ditunjukkan oleh neraca bank, seperti rasio kredit tak lancar terhadap total aktiva yang meningkat. Apabila hal tersebut tidak diatasi, masalah itu dapat menggangu kelangsungan usaha bank. Bank yang terdaftar daftar mengawasan dianggap sebagai bank bermasalah dan diperiksa lebih oleh pengawas bank jika dibandingkan dengan bank yang tidak bermasalah. Bank yang peringkat CAMEL diatas 81 maka bank dengan pendapatan kuat, peringkat CAMEL tidak pernah diinformasikan secara luas.

\subsection{Faktor Permodalan (Capital)}

Modal secara umum adalah sejumlah dana yang ditanamkan kedalam suatu perusahaan oleh para pemiliknya untuk pembentukan suatu badan usaha dan menghendaki agar uang yang ditanamkannya memberikan hail. Sedangkan modal bank adalah dana yang diinvestasikan oleh pemilik dalam rangka pendirian badan usaha yang dimaksudkan untuk membiayai kegiatan usaha bank disamping untuk memenuhi regulasi yang ditetapkan oleh otoritas moneter. Presentase kebutuhan modal minimum yang diwajibkan menurut Bank of International Settlement (BIS) disebut Capital Adequacy Ratio (CAR). Standar yang ditetapkan oleh Bank Indonesia SE BI No.13/24/DPNP 25 Oktober 2011 Rasio CAR dapat dirumuskan sebagai berikut:

$$
\mathrm{CAR}=\frac{\text { Modal }}{\text { Aktiva Terbilang Menurut Resiko }} \times 100 \%
$$




\subsection{Faktor Kualitas Aset (Assets Quality)}

Untuk menilai jenis-jenis aset yang dimiliki oleh bank. Penilaian aset harus sesuai dengan peraturan oleh Bank Indonesia dengan memperbandingkan antara aktiva produktif yang diklasifikasikan dengan produktif. Kemudian rasio penyisihan penghapusan aktiva produktif terhadap aktiva produktif diklasifikasikan. Rasio ini dapat dilihat dari neraca yang telah dilaporkan secara berkala kepada Bank Indonesia. Rumus untuk menghitung KAP sebagai berikut :

$$
\mathrm{KAP}=\frac{\text { Aktiva Produktif Diklasifikasikan }}{\text { Aktiva Produktif }} \times 100 \%
$$

\subsection{Faktor Manajemen (Management)}

Penilaian didasarkan kepada manajemen permodalan, manajemen aktiva, manajemen rentabilitas, manajemen likuiditas dan manajemen umum. Manajemen bank dinilai atas dasar 250 pertanyaan yang diajukan. Penilaian manajemen merupakan manajemen terhadap kemampuan manajemen pengurus bank untuk menjalankan usahanya, kecukupan risiko, serta adanya kepatuhan bank terhadap ketentuan yang berlaku. Hal ini didukung dengan adanya komitmen untuk melaksanakan tugasnya dengan sebaik-baiknya pada Bank Indonesia. Manajemen yang baik dalam suatu bank diharapkan dapat memelihara kesehatan bank.

\subsection{Faktor Rentabilitas (Earning)}

Rasio rentabilitas atau profitabilitas adalah rasio untuk menilai kemampuan perusahaan dalam mencari keuntungan. Rasio ini juga memberikan ukuran tingkat efektivitas manajemen suatu perusahaan. Bank Indonesia menilai kondisi rentabilitas perbankan di Indonesia didasarkan pada 2 (dua) indikator antara lain :

1. Rumus untuk menghitung ROA adalah :

$$
\mathrm{ROA}=\frac{\text { Laba Sebelum Pajak }}{\text { Total Aktiva }} \times 100 \%
$$

2. Rasio Beban Operasional terhadap Pendapatan Operasional (BOPO).

$$
\text { BOPO }=\frac{\text { Beban Operasi }}{\text { Pendapatan Operasi }} \times 100 \%
$$

\subsection{Faktor Likuiditas (Likuidity)}

Rasio likuiditas adalah rasio yang mengukur kamampuan perusahaan memenuhi kewajiban jangka pendeknya. Rasio-rasio ini dapat dihitung melalui sumber informasi tentang modal kerja yaitu dari aktiva lancar dan hutang lancar. Dengan demikian rasio likuiditas berpengaruh dengan kinerja keuangan perusahaan sehingga rasio ini memiliki hubungan dengan harga saham perusahaan. Penilaian kualitatif pada penelitian ini menggunakan Loan to Deposito Ratio (LDR).

$$
\text { LDR }=\frac{\text { Kredit yang diberikan }}{\text { Dana Pihak Ketiga }} \times 100 \%
$$

\subsection{Penilaian Kesehatan Bank Menurut Bank Indonesia}

Penilaian tingkat kesehatan bank di Indonesia sampai saat ini berdasarkan SE BI No.13/24/DPNP 25 Oktober 2011 tersebut juga ditetapkan bobot masing-masing untuk Faktor CAMEL (Capital, Asset, Management, Earning, Liquidity) [3]. Faktor CAMEL dapat dijabarkan sebagai berikut :

Tabel 1. Faktor Penilaian, Rasio dan Bobotnya dalam Penilaian Kesehatan Bank

\begin{tabular}{cccc}
\hline No. & Faktor CAMEL & Rasio & Bobot \\
\hline 1 & Permodalan & CAR & $30 \%$ \\
2 & Aset & KAP & $25 \%$ \\
3 & Manajemen & NPM & $25 \%$ \\
4 & Rentabilitas & ROA & $5 \%$ \\
& & BOPO & $5 \%$ \\
5 & Likuiditas & LDR & $10 \%$ \\
\hline
\end{tabular}

Dalam melakukan penilaian atas tingkat kesehatan bank pada dasarnya dilakukan dengan pendekatan kualitatif atas berbagai faktor yang mempengaruhi terhadap kondisi dan perkembangan suatu bank. Pendekatan tersebut dilakukan dengan menilai faktor-faktor permodalan, kualitas aktiva produksi, manajemen, rentabilitas dan likuiditas. Kemudian dilakukan penilaian terhadap komponen masing-masing faktor dengan sistem kredit yang dinyatakan dalam nilai kredit antara 0 sampai 100 . Selanjutnya masih dievaluasi lagi dengan memperhatikan bobot dari masing-masing faktor, sehingga pada akhirnya akan 
diperoleh suatu angka yang dapat menentukan predikat kesehatan bank, yaitu Sangat Sehat, Sehat, Cukup Sehat, Kurang Sehat dan Tidak Sehat.

\subsection{Metode Analisis Data}

Obyek penelitian adalah PT. Bank Aceh, dengan mengunduh data laporan keuangan dari situs resmi Bank Indonesia. Jenis data berupa data sekunder berupa laporan keuangan tahun 2010-2014. Metode yang digunakan dalam penelitian ini adalah metode deskriptif dengan pendekatan kuantitatif, yaitu dengan cara menganalisis Laporan Keuangan yang kemudian ditabulasikan untuk kategori perusahaan perbankan tersebut dapat dikatakan sehat atau tidak sehat. Penelitian studi kasus merupakan suatu penelitian yang mencoba untuk mencermati individu atau sebuah unit secara mendalam [4]. Penelitian deskriptif menggambarkan apa adanya tentang suatu variabel gejala atau keadaan.

\section{ANALISA DAN PEMBAHASAN}

Aspek-aspek penilaian dalam menentukan kondisi suatu bank biasanya menggunakan berbagai alat ukur. Salah satu alat ukur utama yang digunakan untuk menentukan kondisi suatu bank dikenal dengan nama Analisis CAMEL (Capitelm Assets, Management, Earning, and Liquidity). Hasil dari masing-masing aspek ini kemudian akan menghasilkan kondisi suatu bank. Hasil penilaian dan perhitungan predikat tingkat kesehatan Bank Aceh ditinjau dari analisi CAMEL pada tahun 2012 sampai dengan 2014 adalah sebagai berikut:

\section{a. Faktor Permodalan (Capital)}

Pada faktor permodalan yang diukur dengan rasio CAR, selama tahun 2012 - 2014, PT. Bank Aceh berada pada peringkat satu dari peringkat kesehatan bank yang ditetapkan oleh Bank Indonesia. Kondisi ini mencerminkan bahwa Bank Aceh mampu mengatasi pengaruh negatif kondisi perekonomian dan industri keuangan. Nilai CAR dari Bank Aceh selama kurun waktu 2012-2014 juga relatif stabil, walaupun terjadi penurunan 2013, namun tidak signifikan. Penurunan ini disebabkan terjadinya penurunan nilai total Ekuitas pada tahun 2013.

\section{b. Faktor Kualitas Aset (Assets Quality)}

Berdasarkan aspek kualitas aset, PT. Bank Aceh juga menunjukkan kinerja yang sangat baik, hal ini ditandai dengan kemampuan PT. Bank Aceh memperoleh nilai di atas 0,99. Hal ini menunjukkan tingkat kesehatan Bank Aceh berada pada Peringkat 1. Pada pengelolaan asset beararti Bank Aceh mampu mengatasi perngaruh negatif kondisi perekonomian dan industri keuangan. Hasil perhitungan memang terlihat nilai KAP mengalami penurunan dari tahun 2012 sampai 2014. Namun penurunan ini tidak signifikan sehingga kualitas asset Bank Aceh masih dalam katagori Peringkat 1.

c. Faktor Manajemen (Management)

Dalam penelitian ini, analisis rasio manajemen tidak dilakukan karena adanya keterbatasan yang ada. Pembatasan ini dilakukan mengingat bahwa untuk dapat melakukan penilaian tingkat kesehatan suatu bank, tidak cukup hanya mendasarkan pada analisis terhadap laporan keuangan yang dipublikasikan saja, tetapi juga data-data pendukung lainnya yang bersifat internal. Data yang berhubungan dengan aspek manajemen tidak dapat diperoleh hanya dengan mengandalkan dari data publikasi bank, tetapi harus melalui survey kuesioner dan wawancara. Di Indonesia, hanya Bank Indonesia dan bank yang bersangkutan saja yang dapat mengetahuinya.

d. Faktor Rentabilitas (Earning)

\section{Return On Asset (ROA)}

Renturn on Assets PT. Bank Aceh menunjukkan angka yang sangat baik karena selalu berada diatas angka 3,00 (tiga). Posisi ini menunjukkan kesahatan Bank Aceh yang diukur dnegan ROA berada pada Peringkat 1, karena Bank Indonesia menetapkan angka $>1,5 \%$ sebagai katagori sangat sehat. Kondisi ini menunjukkan Bank Aceh mampu mengatasi perngaruh negatif kondisi perekonomian dan industri keuangan.

\section{Beban Operasional Pendapatan Operasional (BOPO)}

BOPO yang dihitung dengan membandingkan beban operasional dengan pendapatan operasional, diperoleh angka di atas $70 \%$ selama tiga tahun (2012-2014) atau berada dalam Peringkat 1 menurut tingkat kesehatan bank yang telah ditetapkan Bank Indonesia. Kondosi ini menunjukkan bahwa PT. Bank Aceh mampu mengatasi pengaruh negatif kondisi perekonomian dan industri keuangan.

\section{e. Faktor Likuiditas (Liquidity)}

Dalam menilai faktor likuiditas digunakan rasio LDR. Nilai LDR yang diperoleh Bank Aceh dari tahun 2012-2014 menunjukkan kenaikan menjadi 92,83 pada tahun 2014. Nilai ini berada di bawah $100 \%$, yang berarti menurut SE BI No.13/24/DPNP 25 Oktober 2011 berada dalam kondisi tingkat kesahatan bank Sangat Sehat. Hal ini menunjukkan bahwa PT. Bank Aceh mampu mengatasi pengaruh kondisi negatif perekonomian dan industri keuangan.

\section{KESIMPULAN}

Berdasarkan pembahasan maka dapat disimpulkan bahwa tingkat kesehatan PT. Bank Aceh yang diukur dengan menggunakan metode CAMEL berada pada tingkat sangat sehat, ditandai dengan Capital Adequacy Ratio (CAR) tahun 20122014 memiliki modal yang stabil yaitu 17,72\%. Kualitas Aktiva Produktif (KAP) tahun 2012-2014 memiliki kualitas aset yang sangat baik yaitu $>2 \%$. Rasio Return on Asset (ROA) selama tahun 2012-2014 semakin baik yaitu >1,5\%. Rasio Beban Operasional Pendapatan Operasional (BOPO) selama tahun 2012-2014 semakin baik yaitu > 70\%. Loan To Deposit Ratio (LDR) setiap tahunnya relatif stabil. Nilai LDR yang diperoleh Bank Aceh dari tahun 2012-2014 menunjukkan kenaikan menjadi 92,83\%. Nilai ini berada di bawah $100 \%$, yang berarti menurut Surat Edaran Bank Indonesia No 14/45/DPN November 2013 berada dalam kondisi tingkat kesehatan bank Sangat Sehat. 


\section{REFERENCES}

[1] Supriyanto, S. (2018). PENGARUH KINERJA KEUANGAN TERHADAP PENDAPATAN SAHAM PERBANKAN DI BURSA EFEK INDONESIA. Jurnal Bis-A: Jurnal Bisnis Administrasi, 2(1), 39-53.

[2] Supriyanto, S., \& Lestari, W. (2015). ANALISIS KINERJA KEUANGAN DENGAN MENGGUNAKAN METODE ECONOMIC VALUE ADDED PADA PT. BANK MANDIRI (PERSERO), TBK. Jurnal Bis-A: Jurnal Bisnis Administrasi, 4(1), 53-61.

[3] Arikunto, S (2010). Prosedur Penelitian Pendekatan Praktik. Jakarta : Rineka Cipta.

[4] Bank Indonesia (2011), Surat Edaran BI No.13/24/DPNP 25 Oktober 2011 